\title{
The Original Subaltern
}

\section{Citation}

Smail, Daniel Lord. 2010. The original subaltern. Postmedieval: A Journal of Medieval Cultural Studies 1(1-2): 180-186.

\section{Published Version}

doi:10.1057/pmed.2010.19

\section{Permanent link}

http://nrs.harvard.edu/urn-3:HUL.InstRepos:8947969

\section{Terms of Use}

This article was downloaded from Harvard University's DASH repository, and is made available under the terms and conditions applicable to Open Access Policy Articles, as set forth at http:// nrs.harvard.edu/urn-3:HUL.InstRepos:dash.current.terms-of-use\#OAP

\section{Share Your Story}

The Harvard community has made this article openly available.

Please share how this access benefits you. Submit a story.

Accessibility 


\section{The Original Subaltern}

Abstract. This essay invites readers to consider how exclusions operate in the framing of history. In conventional historical thought, agency was accorded only to the limited few. Marginals, ranging from third world nations to subaltern groups of all types, were excluded from the making of history. The task of recuperating the historicity of marginals has been underway now for decades. As I hope to suggest in this essay, however, we have yet to restore historicity to the original subalterns: the peoples of the Paleolithic. The field of Medieval Studies, curiously enough, is implicated in their exclusion. In the developmental narratives that emerged early in the twentieth century, medieval Europe was presented as the point of origins from which modernity sprang. To the extent that medievalists continue to reaffirm the prehistoricity of the Great Before, they instantiate the very same historical exclusion that modernists currently impose on the middle ages.

Keywords. Time revolution, medieval history, Paleolithic people

This is a set of ruminations about the trauma of the time revolution, the moment, in the $1860 \mathrm{~s}$, when human history was cut loose from the history of the world and left to wander on its own. The time revolution is central to the disciplinary histories of geology, biology, and archaeology. Over the course of a single decade, the scholarly community accepted as fact both deep geological time and deep human ancestry. Yet the awareness of deep time took decades to filter into the mainstream understanding of human history. Only by the 1920 s did prehistory enter more vividly into the historical imagination. 
The 1920s was also the founding decade of medieval studies in North America. The simultaneity of these two developments is not accidental, for medieval history slid neatly into the narrative void created by the collapse of Eden. Medieval history presented itself as a kind of Paleolithic substitute, an ersatz point of modern origins that could supplant the need to study the real thing. Medieval studies, which today is so fretfully defensive about its exclusion from the center of gravity in the postmodern academy, was itself founded on the exclusion of a deeper past.

\section{2}

Without the pre-human it is hard to imagine the post/human. Without a prehistory, the dappled shadings of humanity extend across space rather than time. Monsters are displaced onto the wondrous East, Ireland, or other strange places. But with the final shattering of the short chronology, as the dark abyss of time opened up as a practical reality rather than a speculative heresy, the axis of monstrosity shifted 90 degrees and came to rest in the depths of time. The distinguishing signs of monstrosity used to be single feet, dogs-heads, and faces in the chest. Displaced in time, they became shrunken heads, prognathous jaws, glowering brow ridges, and the savage mores of the Killer Ape. Recognizably human, but less than human.

In the wake of Wells's Outline of History (1919), the popular images of prehistory develop apace - in cartoons, in diet manuals, in Paleofiction, in Hollywood, and elsewhere. Ancestral status was not contemplated without a frisson of fear and excitement. Hendrik van Loon describes a creature that was half ape and half monkey, a creature of strange grunts. He tells the children at his feet that 'this creature, though you may hardly believe it, was your first “man-like" ancestor' $(1921,8)$. That was a thought: 
your ancestor. So when Ann Miller sings 'Modern Man is Not For Me' in the musical On the Town (1949), the thrill that runs through the song is both miscegenistic and Oepidal:

Modern man is not for me

The movie star and dapper Dan

Give me the healthy Joe from ages ago

A prehistoric man.

What has Gable got for me?

Or Mrs. Johnson's blond boy, Van?

I want a happy ape with no English drape

A prehistoric man.

\section{幽}

This scene takes place in the American Museum of Natural History, in front of a stuffed caveman who stands mute, staring blankly into the middle distance. The caveman does not get to speak. By the late nineteenth or early twentieth century, others of his kind were fashioned from clay, absent the spark, and placed in frozen dioramas in natural history museums all around the world. They were paralleled, at the Paris Expo of 1889, by living tableaux of primitive peoples in cages. The commodification of the primitive has now attracted the acerbic attention of historians and activists. Subalterns all around the world today have their advocates. But who advocates for the stuffed caveman in On the Town?

The peoples of the Paleolithic are the original subaltern. Onto them we project every fault, ranging from sore backs to impacted wisdom teeth. It's their fault that we are afraid of the dark. It's their fault that grown men like to run away with younger 
girlfriends. Our violence stems from what H.G. Wells called the "primordial fierce combativeness of the ancestral man-ape'(Baker, 1990, 32). Since the moral mirror always reflects antithetical images, the Paleolithic is simultaneously the era of gender equality, the natural diet, and the 'happy Joe'. However we contemplate them, they are always caricatures.

So deep is their subalternity that the people of the Paleolithic don't even have a name. We call them by their species designation, because they are not-quite-human. More recent ancestors are sometimes called 'anatomically modern humans', humans in body though not in thought and culture. Most authors find it next to impossible to call them 'we' or 'us'. Apart from paleoanthropologists, no one wants to advocate for the Paleoliths. Late modernists are disinterested. Feminists and students of culture view them as the unwitting carriers of the natural and the essential. Ethnologists spurn the association, since the political consequences of associating modern foragers with Paleoliths are very grave.

Historians are no better. In the traumatic wake of the time revolution, historians found that they had to score a rupture onto time's chronology, for it was an odd feature of the new history that historicity, if it was to be accorded to some, had to be denied to others. The selective denial of history to the historyless peoples was one of the bizarre things generated by the time revolution. Yet the logic is inexorable. The time revolution, after all, exposed a genealogy extending back indefinitely, connecting us to chimpanzees, fruit flies, and even bananas. Surely we would deny historicity to animals like cats and dogs and horses, the trio cited by Van Loon. 
'The beast lives unhistorically', wrote Nietzsche one day, as he was ruminating on cattle $(1957,1)$. Problems arise, then, when historyful humanity merges with historyless animals: because, by definition, there has to have been a moment in time when history began. This is the logic invoked by figures like Hegel and Ranke to deny historicity to China and India and Africa. If historicity could be denied animals, it could also be denied to whole races of humankind. We have now restored historicity to the peoples without history - except, that is, to the Paleoliths. For once again, who is there to advocate for them?

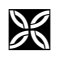

Hegel and Ranke contemplated the 'eternal standstill' of the non-European civilizations. Henry Sumner Maine, more pessimistic, felt that it was actually unusual to find civilizations that are on the move. And during the twentieth century, the Paleoliths, as the original subalterns, were soon constituted as the original stationary society. 'Our imagination fails us when we try to see in the mind's eye the uncounted generations of Paleolithic people', writes one set of textbook authors in 1958. 'We know what men have proved capable of accomplishing - their sciences and arts and great civilizations. Why, then, did they live for so long in the wilderness?'(Hoffman, 28). Two decades later: 'During those long, long centuries the advance of the human animal was enormously slow' (Brinton et al., 1976, 8). It was a primitive dystopia.

The 1920s was the decade that witnessed both the popularization of prehistory and the take-off of medieval studies. It was also the decade that saw the emergence of dystopian literature. A marked feature of dystopian literature, from Yevgeny Zamyatin's We (1922) to Aldous Huxley's Brave New World (1932) and beyond, is that their authors 
often imagined a place, an appalling place, located at the end of time. As E.M. Cioran has written, a utopia is 'a static world... ruled by an eternal present, that tense common to all visions of paradise, a time forged in opposition to the very idea of history' $(1987,99)$. There was tangible opposition to history among the leaders of the Brave New World. 'History is bunk', declares the Controller, Mustapha Mond, as he lectures a few Alpha specimens. Mond goes on to describe the campaign against history that took place as the Brave New World was being set up: the closing of museums, the destruction of historical monuments, the suppression of all books published before a certain date (Huxley, 2004, $40,56)$.

There is a reason why utopias have no use for history. Utopian societies simply fall out of the stream of history, for there can be no progress or ambition in a utopia, just successive generations of individuals occupying unchanging positions in a social matrix — a 'crystallization of life' (Zamyatin, 1972, 24). Much the same holds true for a dystopia. If dystopias are characterized by a perfect absence of initiative, if laws and institutions suppress any expression of individual ambition, then a dystopia is the end of history. In the words of the lead character of $W e$, 'the ideal (clearly) is the condition where nothing happens any more' (ibidem).

Utopias and dystopias, according to this logic, can be positioned at the end of history. At the other end of time, things are more problematic-for how can an unchangeable utopia be propelled into the stream of history? The Judeo-Christian tradition invoked a catastrophic expulsion. Primitive dystopias, societies whose inhabitants cannot apprehend the depths of their own misery and have no capacity to escape it, pose similar problems. Once we realize that history did not begin with a bang in 
4004 BC, once we think upon the long aeons of the Paleolithic, we come back to the puzzling question: how, and when, does history begin? What turned historyless animals into historyful humans?

Philosophers since Hesiod have fretted about the triggering moment. Consider what Lucretius has to say in the fifth book of his On the Nature of Things (1995). Here, we find a poetic description of man's evolution, which begins badly enough: beast-like men roaming in packs, feeding on acorns and berries, and flopping to the ground at the fall of night, heedless of shelter. Yet a short while later these same men are making huts and wearing skins; they have mastered fire, lured women into wedlock, developed language, and learned that the weak must be pitied. From there it is but a short step to cities and kings, ownership and envy, and eventually laws and magistrates. The overall scheme, tellingly, is marked by the absence of divine direction, for the original society contained the seeds of its own transformation. One of these was man's imitative ability. Fire came from the taming of lightning, and by observing the effect of the sun on fruit men learned how fire could soften food. Music derived from the warbling of birds. The original Lucretian society, able to lift itself up by its own bootstraps, contained the seeds of its own redemption.

So too for the nasty, brutish world depicted by Thomas Hobbes in the thirteenth chapter of Leviathan, for Hobbes ascribed to men the singular ability to become aware of the depths of their own misery. This very awareness provided them with the necessary incentive to bow their necks to authority (1991). For Giambattista Vico, the engines that propelled mankind out of its abject post-diluvial misery were several and complex. Renouncing their religion, the races of Ham, Japheth, and Shem abandoned their 
marriages and began to couple promiscuously. Losing all ties to place, they wandered the forests, pursing shy, intractable women, who bore children only to leave them to wallow in their own feces. Absorbing nitrous salts from their feces, the children grew larger, an ontogeny unleashed by the loss of the fear of God that would otherwise have tempered their growth. They became giants. But as the soils began to dry up a century or two after the Deluge, the exhalations of the earth generated lightning, whose terrifying sounds restored a humbling fear of the gods. . and so the gigantic races shrank back to normal size (Vico, 1999, 90-91, 111, 139-43).

So it would seem that whereas at the end of history, humankind, like a billiard ball, could end up nestled in the pocket of utopia, the mirror image of primitive human origins in a timeless dystopia doesn't work so well. Hesiod and others might invoke a merciful god who removes the ball from the pocket of dystopia and sets it rolling on the felted slate, but secular historiography in the twentieth century shouldn't invoke this kind of deus ex machina. And yet it did. The problem, again, was time, for once human history was understood to stretch back ever further, it became paradoxically more difficult to explain why nothing happened. It could not be easily imagined as a Lucretian age containing the seeds of its own transformation, for why did those seeds remain dormant for so long? So the shift into history had to follow the narrative arc of Genesis. It had to be described as the product of a sudden, new, and preferably exogenous change, such as climate change, the breakdown of the bicameral mind, or the Neolithic Revolution that expelled humanity from Eden. But the problem of historylessness did not go away, since the civilizations of the ancient world rose and then, spectacularly, fell. So why not focus historical attention on the moment when our civilization first arose, in the aftermath of a 
deluge of Germanic invaders? Medieval European history serves as a convenient Paleolithic substitute, right down to the revolutions. The commercial revolution, the urban revolution, the shift to written record: all of these postulated medieval revolutions are eerily shadowed by their Neolithic counterparts, at the moment when humankind shifted out of Paleolithic historylessness.

\section{8}

The chronology latent in Western Civ textbooks and works of dystopian literature share a vision of stasis-movement-stasis. The phenotypic transformation from pre-human to human to post/human tracks this chronology in reverse. The Paleoliths were humanlike without being human; it was the body that was subject to evolution while culture stood still. Then, in the wake of the Neolithic transition, there came a period of dizzying scalar leaps in social, economic, and demographic complexity. During this time, the human body gelled and became phenotypically stable. Now, as we contemplate the stasis postulated by dystopian literature, the body can shift once again, and become the post/human body. The impetus of the post/human is to flee from the gelled and stable body. We change the shape of noses, breasts, and buttocks. We alter nervous system with drugs. We contemplate cyborgs.

Yet the chronology is the stuff of fancy. You can't point to any body in the pasta Neolithic body, an Upper Paleolithic body, a body of Homo erectus - and say that that's the beginnings of $u s$, and everything before is pre-human. Geneticists tell us that changes to the human genotype have accelerated dramatically in the past several thousand years, a product of tremendous ecological changes. What we have learned from paleoanthropology in recent years, moreover, is that the human phenotype, even in the deep past, has always been open and suggestible to cultural and epigenetic influences. 
Ochres have long been used to color the body. Humans shape their bodies by means of beautiful (or ghastly) mutilations inflicted on ear lobes, necks, and feet. We use innumerable devices like clothing and tools to extend the edges of the phenotype. Humans have been changing their bodies for a long time.

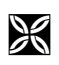

Before the time revolution, history, for most people in the West, began securely in 4004 BC. When the dark abyss of time was definitively opened in the 1860 s, humanity found itself atop a broad plateau, contemplating the brink of a precipice. The great French historian Victor Duruy put it well in 1873 when he spoke of 'an obscure and terrifying antiquity' (une vague et effrayante antiquité) (4). But the edge of the precipice has been eroding ever since the abyss first opened up. The framing of medieval European history, alas, contributed to the erosion of the cliff's edge — and now, the continuing erosion of historical time has swept beyond the solid ground where the medievalists used to stand, in contemplation of future time, their backs confidently to the abyss. The field has been hoist on its own petard. Perhaps it has been justly condemned for turning its back on the original subaltern.

Works Cited.

Baker, Robert S. 1990. Brave New World: History, Science, and Dystopia. Boston, Twayne Publishers.

Brinton, Crane, John B. Christopher, Robert Lee Wolff. 1976. A History of Civilization: Prehistory to 1715. Englewood Cliffs, N.J.: Prentice-Hall.

Cioran, E. M.. 1987. History and Utopia, trans. Richard Howard. New York: pub. check 
Duruy, Victor. 1873. Abrégé d'histoire générale. Paris: Hachette.

Hobbes, Thomas. 1991. Leviathan, ed. Richard Tuck. Cambridge: Cambridge University Press.

Hoffman, Ross J.S., ed. 1958. Man and His History: World History and Western Civilization. Garden City, N.Y.: Doubleday.

Huxley, Aldous. 2004. Brave New World and Brave New World Revisited. New York: Harper Collins.

Nietzsche, Friedrich Wilhelm. 1957. The Use and Abuse of History, trans. Adrian Collins. Indianapolis: Bobbs-Merrill.

Titus Lucretius Carus. 1995. On the Nature of Things, trans. Anthony M. Esolen. Baltimore: Johns Hopkins.

Vico, Giambattista. 1999. New Science: Principles of the New Science

Concerning the Common Nature of Nations, $3^{\text {rd }}$ edition, trans. David Marsh. London: Penguin.

Wells, H.G. 1919. The Outline of History: Being a Plain History of Life and Mankind. London: George Newnes. 